\title{
IN VITRO ANTIBACTERIAL ACTIVITY OF THE ETHANOLIC EXTRACT OF JALOH (SALIX TETRASPERMA ROXB.) LEAVES AGAINST STAPHYLOCOCCUS AUREUS AND PSEUDOMONAS AERUGINOSA
}

\author{
FITRAH WAHYUNI ${ }^{1,2 *}$, URIP HARAHAP ${ }^{3}$, MASFRIA ${ }^{4}$ \\ ${ }^{1}$ Master Programme in Pharmacy, Faculty of Pharmacy, University of Sumatera Utara, Jalan Tri Dharma No. 5, Padang Bulan, Medan, \\ Indonesia. ${ }^{2}$ Loka Litbang Biomedis Aceh, Jalan Bandara SIM Lorong Teungku Dilangga No. 9 Lambaro, Aceh Besar 23371, Indonesia. \\ ${ }^{3}$ Department of Pharmacology, Faculty of Pharmacy, University of Sumatera Utara, Jalan Tri Dharma No. 5, Padang Bulan, Medan, \\ Indonesia. ${ }^{4}$ Department of Pharmaceutical Chemistry, Faculty of Pharmacy, University of Sumatera Utara, Jalan Tri Dharma No. 5, Padang \\ Bulan, Medan, Indonesia. Email: wahyunifitrah@gmail.com \\ Received: 06 December 2017, Revised and Accepted: 06 April 2018
}

ABSTRACT

Objective: This study aims to determine antibacterial activity of ethanolic extract of jaloh (Salix tetrasperma Roxb.) leaves against Staphylococcus aureus (SA) and Pseudomonas aeruginosa (PA).

Methods: Extract was obtained by maceration method of jaloh (S. tetrasperma Roxb.) leaves dried powder with $96 \%$ ethanol as solvent. The antibacterial activities of extract were tested by Kirby-Bauer method against SA and PA. Data were analyzed statistically using Kruskal-Wallis test for significant difference level $\mathrm{p}<0.05$.

Results: Based on the regression test, the equation of regression curve of extract antibacterial activity on SA and PA, respectively, was $y=350.456 x-229.579$ and $y=331.866 x-272.069$. The minimum inhibitory concentrations (MICs) of SA and PA from the equation of regression curve, respectively, were 4.5193 and $6.6039 \mathrm{mg} / \mathrm{mL}$.

Conclusion: Based on the MIC value, ethanolic jaloh leaves extract had a weak antibacterial activity against SA and PA.

Keywords: Antibacterial, Salix tetrasperma Roxb., Jaloh, Staphylococcus aureus, Pseudomonas aeruginosa.

(c) 2018 The Authors. Published by Innovare Academic Sciences Pvt Ltd. This is an open access article under the CC BY license (http://creativecommons. org/licenses/by/4. 0/) DOI: http://dx.doi.org/10.22159/ajpcr.2018.v11s1.26580

\section{INTRODUCTION}

Commonly to treat infectious diseases use antibiotics. The improper usage of antibiotics arise bacterial resistant to one or some type of antibiotic (multiple drug resistance) [1]. For this reason, the effort to search and develop new antibacterials still have been done. New antibacterial sources can be obtained and developed from plants because of the content of secondary metabolites such as saponins, tannins, alkaloids, flavonoids, and terpenoid efficacious as antibacterial $[2,3]$.

There are plant species that grow in Aceh, by people called jaloh or sijaloh (Salix tetrasperma Roxb.), from the Salicaceae family. Utilization of this plant in some areas of Aceh is used as a febrifuge (antipyretic) [4]. Salicaceae family plant contains the main compounds of phenols such as flavonoids and tannins [5].

Based on that, jaloh plants have potential as antibacterial. This study aims to determine the antibacterial activity of jaloh plants.

\section{METHODS}

\section{Chemical and reagents}

Ethanol 96\% (Merck), dimethyl sulfoxide (DMSO) (Merck), medium nutrient agar (oxoid), nutrient broth (oxoid), Mueller-Hinton agar (oxoid), aqua bidestilata sterile (Ikapharmindo Putramas), and $\mathrm{NaCl}$ 0.9\% (Widatra Bhakti) were used.

\section{Bacterial strains}

Bacteria test culture was Gram-positive Staphylococcus aureus (SA) ATCC 6538 and Gram-negative Pseudomonas aeruginosa (PA) ATCC 9027 obtained from Microbiology Laboratory of Faculty of Pharmacy USU, Medan, Indonesia.

\section{Plant materials}

Jaloh plant (S. tetrasperma Roxb.) was collected from Lambaro Angan village, Aceh Besar, Aceh Province, Indonesia.

\section{Preparation of extracts}

A total of $600 \mathrm{~g}$ of jaloh leaves dried powder was macerated with $6 \mathrm{~L}$ ethanol 96\% [6]. The macerate was then distilled and evaporated under reduced pressure at a temperature of not more than $50^{\circ} \mathrm{C}$ using a rotary evaporator to obtain a viscous extract [7].

\section{Antibacterial activity assay}

The antibacterial activity test was performed by Kirby-Bauer method by as much as $0.1 \mathrm{~mL}$ inoculum of each bacterium SA and PA $10^{6} \mathrm{CFU} / \mathrm{mL}$ mixed homogeneously with $15 \mathrm{~mL}$ Mueller-Hinton Agar in a petri dish, then left until medium solidified. Thereafter, paper disc was impregnated by $10 \mu \mathrm{L}$ of each extract solution in DMSO concentration of $500,250,125.62 .5,31.25,15.625$, and $7.8125 \mathrm{mg} / \mathrm{mL}$ implantation to the medium for $10 \mathrm{~min}$ to diffuse and then incubated at $36-37^{\circ} \mathrm{C}$ for $24 \mathrm{~h}$. Furthermore, each Petri was measured the diameter of the transparent zone (inhibition zone) around the disc using the sliding term $[7,8]$. The test was conducted 5 times. The minimum inhibitory concentration (MIC) of the extract was determined using the regression equation from the graph of square inhibition zone diameter $(\mathrm{mm})$ to the concentration log and the intersection on the $\mathrm{X}$-axis recorded as MIC $[9,10]$.

\section{Statistical analysis}

Data were analyzed statistically using Kruskal-Wallis test with significant different level $\mathrm{p}<0.05$. This statistical analysis was performed using the Statistical Product and Service Solution program version 18. 


\section{RESULTS}

The inhibitory zone formed around the papermaking indicates that the extract has antibacterial activity against Gram-positive SA and Gramnegative PA bacteria. The mean diameter of the inhibitory extract zone is shown in Table 1.

The values of the inhibitory zone diameters shown in Table 1 were greater by increasing the concentration of extracts tested against SA and PA. Based of Kruskal-Wallis test, it showed significant difference $(p<0.05)$. meaning that the various extract concentration produced significant difference to the diameter of the inhibition zone of SA and PA.

Table 1 also shows the extract inhibitory zone diameter in SA greater than PA. Based on the Kruskal-Wallis test, in addition to concentrations, different types of test bacteria also caused a significant difference $(\mathrm{p}<0.05)$ against the inhibitory zone diameter. However, the inhibitory zone diameter formed in SA and PA with extract concentration of $15.625,250$, and $500 \mathrm{mg} / \mathrm{mL}$ did not differ significantly $(\mathrm{p}>0.05)$.

Based on the regression test, the regression equation curve of antibacterial activity of extract on SA and PA as shown in Fig. 1 was each $y=350.456 x-229.579$ and $y=331.866 x-272.069$. MIC is the antilog value of the intersection on the $\mathrm{x}$-axis of the regression equation so that MIC extract of SA and PA was 4.5193 and $6.6039 \mathrm{mg} / \mathrm{mL}$, respectively.

\section{DISCUSSION}

The results of the antibacterial activity test of jaloh plants as presented in Table 1 show the differences with the results obtained by Islam

Table 1: Effect of concentration of ethanolic extract of jaloh (S. tetrasperma Roxb.) leaves against zone inhibition zone diameter of SA and PA

\begin{tabular}{lll}
\hline Extract concentration & \multicolumn{2}{l}{$\begin{array}{l}\text { Inhibition zone diameter }(\mathbf{m m} \pm \mathbf{S D}, \\
\mathbf{n = 5})\end{array}$} \\
\cline { 2 - 3 } & $\mathbf{S A}$ & $\mathbf{P A}$ \\
\hline $7.8125 \mathrm{mg} / \mathrm{mL}$ & 12.070 .8013 & $9.22 \pm 0.8672$ \\
$15.625 \mathrm{mg} / \mathrm{mL}$ & $13.12 \pm 1.6977^{*}$ & $10.44 \pm 0.9711^{*}$ \\
$31.25 \mathrm{mg} / \mathrm{mL}$ & $16.13 \pm 0.5287$ & $13.82 \pm 0.3421$ \\
$62.5 \mathrm{mg} / \mathrm{mL}$ & $19.22 \pm 0.2775$ & $16.82 \pm 0.8136$ \\
$125 \mathrm{mg} / \mathrm{mL}$ & $21.88 \pm 0.5718$ & $20.14 \pm 0.2510$ \\
$250 \mathrm{mg} / \mathrm{mL}$ & $24.51 \pm 0.4450^{*}$ & $22.94 \pm 2.5716^{*}$ \\
$500 \mathrm{mg} / \mathrm{mL}$ & $27.78 \pm 0.4087^{*}$ & $25.84 \pm 6.4802^{*}$ \\
\hline
\end{tabular}

*Not significant difference ( $\mathrm{p}>0.05)$. S. tetrasperma: Salix tetrasperma, $\mathrm{S}$.

SA: Staphylococcus aureus, PA: Pseudomonas aeruginosa, SD: Standard deviation et al. [11]. The antibacterial activity of natural compounds can be different because it is influenced by growing places, harvest time, and extraction methods. Extraction procedures that use chemicals or heating may alter the content of active compounds, functions, and natural characteristics or may produce unsafe compounds. The chemical structure and concentration of the plant's active components also determine its antibacterial properties [5]. Increased concentrations of the extracts mean that the antibacterial compound is higher and the diameter of the inhibitory zone is greater.

Flavonoids and tannins are phenol group compounds that become the main compound of plant jaloh. Phenol compounds are polar. A compound has maximum antibacterial activity when it has optimum polarity because hydrophilic-lipophilic balance is required in the interaction of an antibacterial compound with bacteria. The location and number of hydroxyl groups in the phenol group are thought to be related to toxicity to microorganisms. The mechanism of the action of phenol compounds will generally interact with proteins present in the cell wall or cytoplasm through hydrogen bonding and hydrophobic interactions. This compound disrupts the membrane function and affects the membrane protein, resulting in changes in the structure and function and permeability of bacterial cells, causing the loss of macromolecules from within the cell. Phenol compounds at high concentrations can cause protein denaturation. Another mechanism is to interfere with the activity of enzymes in cells. This can occur at low concentrations $[5,12,13]$

Flavonoids are synthesized by plants in reaction to bacterial infections, so when tested in vitro with various microorganisms, show effective results as an antibacterial compound. Its activity may be related to the ability of these compounds to form complexes with extracellular and dissolved proteins and bacterial cell walls. Lipophilic flavonoids can also interfere with microbial membranes. The bacterial cell membrane is damaged in the phospholipid part so that the permeability becomes reduced $[14,15]$.

Tannin acts as an antibacterial possibility regarding its ability to: (i) Bind to proteins and adhesins and inhibit enzymes, (ii) form complexes with cell walls and metal ions, and (iii) disrupt plasma membranes. Complexes formed with proteins through hydrogen bonds cause the protein to be denatured so that bacterial metabolism becomes impaired $[15,16]$.

Anthraquinone has very reactive characteristics. It is known to form a non-reversible complex with nucleophilic amino acids in proteins, thereby causing the protein to become inactive and to lose cell function. This makes the potential coverage of anthraquinone antibacterial effects very good. Possible targets in bacterial cells are adhesins, cell wall polypeptides, and enzymes resulting in bacterial death. Anthraquinone also makes substrate unavailability for bacteria $[14,17]$.

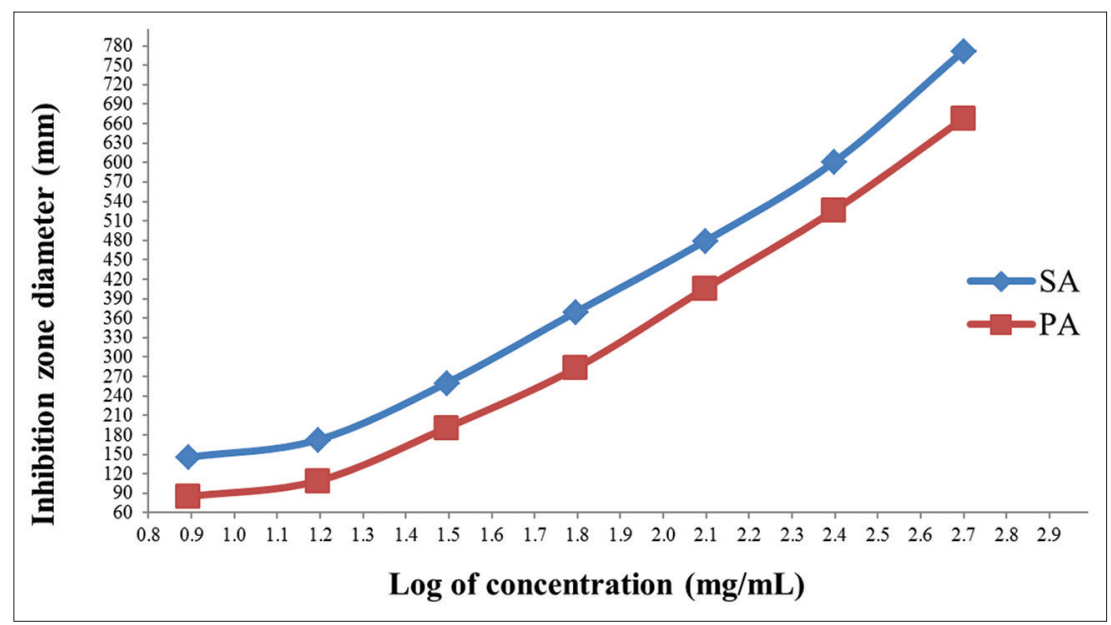

Fig. 1: Regression curve of ethanolic extract of jaloh (Salix tetrasperma Roxb.) leaves against Staphylococcus aureus and Pseudomonas aeruginosa 
The mechanism of action of terpenoid compounds is not fully understood but is thought to interfere with membrane formation by lipophilic compounds [14]. The ability of terpenoids damages cell membranes, deactivates enzymes, and denatures proteins causing the permeability of bacterial cell walls to decrease so that cell walls are damaged $[14,18]$.

Antibacterial activity is also affected by the type of bacteria. Grampositive bacteria SA and Gram-negative PA have differences in thickness and cell wall components. SA cell wall consists only of a thick layer of peptidoglycan with a lipid content of $1-4 \%$ and a water soluble polysaccharide (acidic acid) so that the cell wall of bacteria is polar. Since the structure is simpler so as to facilitate the antibacterial compound into the cell and find the target of work and this causes Gram-positive tends to be more sensitive to antibacterial, whereas PA has a thinner peptidoglycan layer with the lipid content of $11-22 \%$, the structure has an outer membrane composed of the outer lipopolysaccharide and the inner phospholipids so as to be nonpolar. The outer membrane serves as a protector of toxic substances including antibacterials so as to prevent antibacterial penetration into the work target and this causes the antibacterial to be less effective. Polar compounds more easily penetrate the peptidoglycan layer than the lipid layer $[13,15]$.

According to Sartoratto et al. (2004) in Fernandes et al., antibacterial activity with MIC $50-500 \mu \mathrm{g} / \mathrm{mL}$ is strong, $600-1500 \mu \mathrm{g} / \mathrm{mL}$ is moderate, and above $1500 \mu \mathrm{g} / \mathrm{mL}$ is weak [16]. Other literature sources mention that crude extracts are said to be active if they have $<8 \mathrm{mg} /$ $\mathrm{mL}$ of MIC. MIC crude extracts and insulating compounds, respectively, above 1 and $0.1 \mathrm{mg} / \mathrm{mL}$ are recommended to avoid. Current research considers that MIC $<1 \mathrm{mg} / \mathrm{mL}$ has good activity [19]. Based on this, the antibacterial activity of ethanol extract of jaloh leaves against SA and $\mathrm{PA}$ is weak.

Most plant secondary metabolites have weak antibacterial activity, even less activity than antibacterial compounds produced by bacteria and fungi. Due to the synergistic mechanisms between plant compounds, even though their antibacterial potency is lacking, plants successfully fight infection well [16]. Plants with compounds that have no intrinsic antibacterial activity are capable of making bacteria susceptible to previously ineffective antibiotics $[20,21]$

\section{CONCLUSION}

Leaf ethanol extract had a weak antibacterial activity against SA and PA with MIC values of 4.5193 and $6.6039 \mathrm{mg} / \mathrm{mL}$, respectively.

\section{ACKNOWLEDGMENT}

The authors would like to acknowledge the PPSDM Ministry of Health for funding this research, Dean and Head of Master Program Faculty of Pharmacy University of Sumatera Utara, Prof. Dr. Rosidah, M.Si., Apt., and Prof. Dr. Jansen Silalahi, M.App.Sc., Apt for the support.

\section{CONFLICTS OF INTEREST}

The authors declare that there is no conflict of interest regarding the publication of this paper.

\section{REFERENCES}

1. Utami ER. Antibiotics, resistence and rationality of therapy. Sainstis 2012;1:124-5

2. Alamzeb M, Khan MR, Ali S, Ur-Rashid M, Khan AA. Bioassay guided isolation and characterization of anti-microbial and anti-trypanosomal agents from Berberis glaucocarpa Stapf. Afr J Pharm Pharm 2013;6:2564 .

3. Abdallah EM. Plants: An alternative source for antimicrobials. J Appl Pharm Sci 2011;1:18.

4. Sugito S, Manalu W, Astuti DA, Handharyani E, Chairul. Intestinal Morphometrics and broiler chicken performance with heat recovery and n-hexane skin extract 'Jaloh' (Salix tetrasperma Roxb). Livest Media 2007:30:199.

5. Hayek SA, Gyawali R, Ibrahim SA. Antimicrobial natural products. In: Vilas AM, editor. Microbial Pathogens and Strategies for Combating Them: Science, Technology and Education. Formatex. Halaman; 2013. p. 915-6.

6. Depkes RI. Pharmacope of Indonesian. $3^{\text {rd }}$ ed. Jakarta: Departemen Kesehatan RI; 1979. p. 33, 649, 696

7. Depkes RI. Pharmacope of Indonesian. $4^{\text {th }}$ ed. Jakarta: Departemen Kesehatan RI; 1995. p. 891-9.

8. Mwitari PG, Ayeka PA, Ondicho J, Matu EN, Bii CC. Antimicrobial activity and probable mechanisms of action of medicinal plants of Kenya: Withania somnifera, Warbugia ugandensis, Prunus africana and Plectrunthus barbatus. PLoS One 2013:8:3-4.

9. Ofokansi KC, Attama AA, Uzor PF, Ovri MO. Antibacterial activities of the combined leaf extract of phyllantus muellerianus and ciprofloxacin against urogenital isolates of Staphylococcus aureus. Clin Pharm Biopharm 2012;1:2.

10. Ofokansi KC, Attama AA, Uzor PF, Ovri MO Evaluation of the combined antimicrobial activity of the leaf extract of Phyllantus muellerianus with ciprofloxacin. J Pharm Technol Drug Res 2013;2:2-3.

11. Islam MS, Zahan R, Nahar L, Alam MB, Naznin M, Sarkar GC, et al. Antibacterial, insecticidal and in vivo cytotoxicity activities of salix tetrasperma. Int J Pharm Sci Res 2011;2:2103-6.

12. Stefanovic O, Radojevic I, Vasic S, Comic L. Antibacterial activity of naturally occurring compounds from selected plants. In: Bobbarala V, editor. Antimicrobial Agents. Kroasia: InTech. Halaman; 2012. p. 2-3.

13. Moningka KC, Kojong NS, Sudewi S. Uji aktivitas antibakteri ekstrak daun ekor kucing (Acalypha hispida Burm. F.) terhadap bakteri Staphylococcus aureus dan Escherichia coli secara in-vitro. Pharm J Ilmiah Farmasi 2015;4:198-9.

14. Savola D. Plant-derived antimicrobial compounds: Alternatives to antibiotics. Future Microbiol 2012;7:981-2.

15. Angelina M, Turnip M, Khotimah S. Antibacterial activity test of basil leaf ethanol extract (Ocimum sanctum L.) on bacterial growth. Escherichia coli dan Staphylococcus aureus. Protobiont 2015;4:188.

16. Fernandes TG, de Mesquita AR, Randau KP, Franchitti AA, Ximenes EA. In vitro synergistic effect of Psidium guineense (swartz) in combination with antimicrobial agents against methicillin-resistant Staphylococcus aureus strains. Sci World J 2012;4-6.

17. Omojate GC, Enwa FO, Jewo AO, Eze CO. Mechanisms of antimicrobial actions of phytochemicals against enteric pathogens- $\mathrm{A}$ review. J Pharm Chem Biol Sci 2014;2:82.

18. Roihanah S, Sukoso S, Andayani S. Aktivitas antibakteri ekstrak teripang Holothuria sp. Terhadap bakteri aeromonas hydrophila secara in vitro. J Exp Life Sci 2013:3:42-43.

19. Hossain MA, Park JY, Kim JY, Suh JW, Park SC. Synergistic effect and antiquorum sensing activity of Nymphaea tetragona (water lily) extract. BioMed Res Int 2014;7:2-3.

20. Aiyegoro OA, Okoh AI. Use of bioactive plant products in combination with standard antibiotics: Implications in antimicrobial chemotherapy. J Med Plants Res 2009;3:1147-9.

21. Sartoratto A, Machado AL, Delarmelina C, Figueira GM, Duarte MC, Rehder VL. Composition and antimicrobial activity of essential oils from aromatic plants used in Brazil. Braz J Microbiol 2004;35:275-80. 